\title{
NEST STRUCTURE AND FLIGHTS OF THE ANT Formica obscuriventris \\ Mayr*
}

\author{
BY MARY TALBOT \\ The Edwin S. George Reserve, University of Michigan
}

\begin{abstract}
Nineteen colonies of Formica obscuriventris were discovered between 1951 and 1962 in the two square miles of the Edwin S. George Reserve in southern Michigan. This paper describes flight activities of males and females, atmospheric conditions which allowed or prevented flights and the type of nest in which the winged ants developed and from which they flew.
\end{abstract}

\section{Nest Distribution and Structure}

Most of the 19 colonies were located at places where woods and fields met; six were at woods' edges, three in small clearings, one at a fence row and two among small clumps of trees in fields. Six were in a sandy strip between marsh and woods, and one was on a ridge of an open oakhickory wood.

A distinctive characteristic of the species was the superficial, spread-out nature of their nests. This contrasted charply with nests of the closelyrelated $F$. obscuripes Forel, which built large compact mounds with coarse thatch centres. $F$. obscuriventris' nest chambers were scattered under logs, stones, and piled-up leaves, and could extend over as much as $20 \times 30$ feet. Typically a nest included a protected place with moderately high moisture, as well as outlying parts which were more open and dry. Brood was shifted frequently to take advantage of favourable moisture and temperature. Thatch of finely-chewed leaves was used to seal openings in logs or to help fashion chambers outside of logs.

One colony, known since 1954, was typical in location and structure. The ants dominated an open area of approximately $45 \times 25$ feet on a south sloping hillside. The two large trees, whose fall had created the opening in an oak wood (Quercus velutina Lam.), were projecting uphill 19 feet apart. Their branches were scattered, and all were decayed in some places and firm in others. The clearing was grassy (Poa compressa $\mathrm{L}$.

\footnotetext{
*The work was assisted by a grant from the United States National Science Foundation. Facilities of the University of Michigan's Edwin S. George Reserve were made available by Dr. Francis C. Evans, Assistant Director, and Dr. T. H. Hubbell, Director of the Reserve.
}

and Panicum sphaerocarpon Ell.) with scattered forbs (Verbascum thapsus L., Asclepias syriaca L., Circium arvense (L.) Scop.). Oaks of the nearby woods held a thick moist layer of fallen leaves, but on the sunny slope the leaves collected abundantly only where held by logs and their branches.

The matted leaf layers piled against the largest $\log$ were used extensively for housing larvae and pupae. From here they could be moved readily to take advantage of fluctuating moisture and heat. Brood was also found within the $\log$, just under it, and in chambers extending down into the soil from 2 to 6 inches. At various times brood was found under leaves along 30 feet of the main log. Covered runways extended from the nest to chambers beneath leaves, under stones and to the second $\log 19$ feet to the right. Brood was moved over this entire area, and often eggs and small larvae were found in one place, while piles of large larvae and pupae were distributed some distances away. All brood was moved quickly when exposed, and was not usually brought back to the disturbed place.

A remarkable series of runways was revealed by parting grasses and lifting leaves. These hidden half-tunnels connected all parts between the logs and extended upward 33 feet to a clump of shrubs at the hilltop. Runways were threefourths to one and one-half inches wide, and were dug one to one and one-half inches deep into the soil. They were completely hidden, being roofed over by soil, matted grass and leaves. After the runways were disturbed the ants gave a good demonstration of how they were made. They dug out the soil with their mandibles and scattered it about. They did not construct a roof, but gradually grasses fell over, leaves and soil were caught, and an open ditch became a tunnel. Workers were still repairing runways six weeks after they were disturbed. By this time the heavy line of traffic of foraging ants could still be seen for about three-fourths of the trail, but they were concealed along the rest. (At some nests made in more barren places, the sunken runways never became roofed). 
As the years passed, the large logs decayed until only scattered fragments were left. However, the colony continued to thrive, and year by year shifted its brood to take advantage of the remaining pieces of wood and of several stones. It still dominated the slope, and in 1962 produced its usual yearly crop of winged females.

Another typical colony was found occupying branches of a large limb which had fallen from a black oak in a fence row. On one day ten groups of brood were found scattered among piles of leaves held by branches over an area of $24 \times 20$ feet. Brood was also found in hollowed-out branches filled with thatch. Segregation of brood was distinct. In some places there were only eggs and small larvae; in some, masses of larger larvae; in others, only pupae and large larvae which were ready to pupate. There was a definite gradation of moisture from the deep pile of leaves nearest the trees to sparser and drier leaves at branch tips out in the field. The usual tunneled runways made a labyrinth beneath the leaves.

Covered runways usually extended outward to feeding grounds. From one nest a main tunnel ran 36 feet to a cluster of aspen trees (Populus tremuloides Michx.), 3 to 4 feet high, where ants were attending aphids on branch tips. At least 10 such small trees were connected by runways and each was completely encircled by a tunnel.

\section{Brood Development}

Eggs and larvae were present in early June when observations began. Pupae of workers, males, and females could be found by the middle of June. Winged ants began to emerge as adults about the 15th of July, and all had completed emergence by August 6th. Flights began during the last week of July or the first week of August, and continued until the latter part of August. Times of development of brood and length of flight periods varied slightly from year to year, depending on weather conditions.

\section{Flights}

$F$. obscuriventris had their flights in the morning, as did other species of Formica of the region. Preliminary observations of flights of a colony were made in 1961 to determine time of day and characteristic activities. The 6 observed flights took place between August 17th and August 31st. This colony was selected for more intensive study in 1962 because it produced both males and females. (Some / roduced only females or only males). The colony had taken over a small clearing, made some time in the past when several oaks fell. By 1962 the opening was dotted with young black oak trees, 3 to 10 feet tall, and by smaller black cherries (Prunus serotina Ehrh.). Ground cover was a rather thick growth of bracken (Pteridium aquilinum var. latiusculum (Desv.) Underw.), and sedge (Carex pensylvanica Lam.) together with a few grasses and milkweed. The clearing was surrounded by tall black oaks which moderated temperature and curtailed wind.

The ants made use of a number of isolated branches scattered over $18 \times 24$ feet. Some were hollow and filled with thatch which covered any openings, and even sealed the logs to the ground in places. Some were solid and had chambers formed beneath them and among leaves at their sides. The usual covered runways connected the logs and extended out to the edges of the clearing.

The whole nest was not in complete sunshine until very late (9.30 to 10.00 a.m. E.S.T.) because of the tall trees to the east. However, much earlier, sunlight came through gaps in the trees, and spots of sun touched various parts of the nest area. Two logs 9 feet apart were the first to receive the warming light, and it was from these two only that winged ants emerged in both 1961 and 1962. A thatched end of the back log caught the sun first, and ants always came out first here; then as the sun's rays moved along the log, they appeared at a crack near its top. Action at the front $\log$ was delayed until the sun warmed it a bit later, but because it remained in mottled shade, flying could go on here for considerable time after the back $\log$ in full sun had become too warm for ants to emerge. Thus the ants took advantage of the earliest morning warming, and they prolonged flight time by using shade when temperatures were higher.

Morning activity always started in the same way. When the first sunlight reached the end of the log, workers within the log removed a narrow strip of thatch. As black males began to push out workers came to the surface, and little clusters of 5 to 15 loitered around the opening, trying to keep the males back. When males escaped onto the log, workers pursued and attempted to herd them down by pulling antennae, wings or legs, or even occasionally carrying them. At first this was all slow motion, since neither worker or male could move rapidly in the morning cold. Soon males moved more freely, evaded workers, climbed the $\log$, and 
flew. On unfavourable days, workers continued to try to keep them back; but when flying was good they ceased to hover about and paid no attention. Near the flight's end workers again became active, urging or leading the remaining winged ants back into the nest. Both males and females flew readily and easily. They climbed to good positions and then simply fluttered their wings rapidly but briefly and took off from log, Carex, twigs or bracken leaves. They flew toward the brightest light, which was above the trees toward the east. When an occasional alate fluttered and fell, it climbed immediately for another try.

In 1962 the colony had 16 flights which took place from July 27th through August 24th. (Flying was prevented on 13 days by unfavourable weather). Rising temperature and increasing light proved to be the environmental factors which initiated flight.* Males could come out of the nest at temperatures as low as $57^{\circ} \mathrm{F}$.; they could begin to fly when temperatures reached $63^{\circ} \mathrm{F}$. or $67^{\circ} \mathrm{F}$. (which took an average time of 24 minutes), and flew best at about $68^{\circ} \mathrm{F}$. They seemed unable to take off at temperatures above $72^{\circ} \mathrm{F}$. Females came out at about the same time but delayed their flying until temperatures were a little higher $\left(66^{\circ} \mathrm{F}\right.$. to $69^{\circ} \mathrm{F}$.). Their best flying took place at $69^{\circ} \mathrm{F}$. to $70^{\circ} \mathrm{F}$.

Since the nest was in a protected place, the night cold lingered rather long, and the colony must have flown considerably later than did those receiving early morning sun. The time of beginning of flights varied from 7.00 to $8.43 \mathrm{a} . \mathrm{m}$. (E.S.T.), and endings fluctuated from 7.23 to 10.04 a.m. Length of a flight depended upon favourable conditions and varied from 10 minutes to one hour and thirty-six minutes. (Table I).

The best mornings were cold and bright, making a sharp contrast between shade and sun temperatures. Any decrease in either temperature or light retarded or prevented flying even when this occurred within the normal range of flying. Temperature requirements were rather clear-cut and definite, but the intensities of light favourable for flight varied greatly. The ants would fly during a wide range of brightness, the main

\footnotetext{
*Temperatures were taken 6 to 8 inches above ground surface. This was about the log top level. Light of the sky directly above the log was recorded by a Weston sunlight illumination meter. A Bendex psychrometer gave relative humidity, and a hand anemometer measured wind velocity in miles per hour.
}

requirement being that it was not decreasing. Relative humidity in the morning was generally high and always seemed to be within tolerated range ( 57 per cent. -95 per cent.). Morning dew and wet grasses did not disturb the ants. Neither did a slight breeze. Little gusts of about 2 miles per hour caused a momentary halt in flying, but this much wind was rare in the sheltered place.

A study of the 4 largest flights gave a clear picture of the most favourable environmental conditions. Each morning was bright and sunny after a cold night. Ants came out when they could still move only slowly, and flew as soon as they were warmed by the sun. The flights were long, and as temperatures rose slowly the ants spread widely into the surrounding vegetation, flying from Carex and bracken and small trees for several yards behind the logs. The spreading occurred in one of two ways-either ants tried to fly and dropped a short distance away, or else winged ants came up from their tunnels beneath the leaves.

Smaller flights were not always caused by unfavourable weather. The last two flights were small because the colony was almost depleted of winged forms. And some earlier flights may have represented almost all of the mature alates present in the nest, since flying began before all had emerged from the pupal state. Male pupae were found on August 2nd, a week after flights began, and some females within the nest were not fully pigmented on August 9th.

Inclement weather did clearly account for some sparse flights and for the lack of flights on 13 days. Flights were prevented on 6 days by overcast or darkening skies, on 3 days by rain, and on 4 days by soaked ground from rains the night before. The shortest flight (10 minutes) was delayed by dark sky, and then was cut short quickly when the sun caused sudden warming. On August 20th the urge to fly was very strong, and 14 males flew in spite of an overcast sky and the exceedingly low light record of 120 to 160 foot candles. They were stopped when the foot candle reading dropped to 60 .

$F$. obscuriventris apparently does not produce a great abundance of winged ants. From this colony an estimated 2587 males and 422 females flew. The 3099 total is of course an under-count, since not all of the ants could be seen, especially during abundant flights when they spread greatly. However, there were never great swarms flying at any time. The highest record gave 32 a minute, 
Table I. Formica obscuriventris-Record of 16 Flights in 1962 at the Edwin S. George Reserve, Pinckney, Michigan.

\begin{tabular}{|c|c|c|c|c|c|c|c|c|c|c|c|c|c|c|}
\hline \multirow[t]{2}{*}{ Date } & \multicolumn{3}{|c|}{$\begin{array}{c}\text { First appearance } \\
\text { of alates }\end{array}$} & \multicolumn{3}{|c|}{$\begin{array}{c}\text { Beginning } \\
\text { of flight }\end{array}$} & \multicolumn{3}{|c|}{$\begin{array}{l}\text { Height } \\
\text { of flight }\end{array}$} & \multicolumn{3}{|c|}{$\begin{array}{l}\text { End } \\
\text { of flight }\end{array}$} & $\begin{array}{l}\text { Number of } \\
\text { ants flying }\end{array}$ & \multirow[t]{2}{*}{$\begin{array}{l}\text { Length } \\
\text { of flight }\end{array}$} \\
\hline & Time* & Temp* & Light* & Time & Temp. & Light & Time & Temp. & Light & Time & Temp. & Light & & \\
\hline $7-27$ & $8: 00$ & $65^{\circ}$ & 3000 & $8: 38$ & $65^{\circ}$ & 4600 & $9: 08$ & $67^{\circ}$ & 6000 & $9: 17$ & $68^{\circ}$ & 6400 & $440^{*}$ & $39 \mathrm{~min}$ \\
\hline $7-28$ & $7: 50$ & 64 & 560 & $8: 38$ & 67 & 960 & $8: 45$ & 68 & 1180 & $8: 48$ & 69 & 1180 & $160^{*}$ & $10 \mathrm{~min}$ \\
\hline $8-1$ & $7: 15$ & 58 & 350 & $7: 55$ & 64 & 940 & $8: 07$ & 66 & 1800 & $8: 58$ & 68 & 2400 & $5150^{*}$ & $63 \mathrm{~min}$. \\
\hline $8-2$ & $7: 58$ & 62 & 720 & $8: 04$ & 64 & 2800 & $8: 30$ & 66 & 2400 & $9: 27$ & 71 & 5000 & $222 \hat{O}^{\star}$ & $83 \mathrm{~min}$. \\
\hline $8-3$ & $7: 30$ & 61 & 490 & $7: 55$ & 66 & 1600 & $7: 58$ & 69 & 2000 & $8: 30$ & 71 & 2200 & $18 \AA$ & $35 \mathrm{~min}$. \\
\hline $8-8$ & & & & $7: 37$ & 67 & 700 & $8: 19$ & 70 & 1400 & $8: 25$ & 72 & 1020 & $500^{\star}$ & 48 in. \\
\hline $8-10$ & $7: 50$ & 57 & 300 & $8: 23$ & 64 & 1200 & $9: 14$ & 69 & 1600 & $9: 58$ & 69 & 1400 & $618 ふ$ & $95 \mathrm{~min}$, \\
\hline $8-11$ & $7: 53$ & 60 & 380 & $8: 15$ & 64 & 810 & $8: 22$ & 69 & 3800 & $9: 18$ & 68 & 3800 & 1413 & $63 \mathrm{~min}$. \\
\hline $8-15$ & $8: 10$ & 57 & 960 & $8: 43$ & 65 & 1060 & $9: 24$ & 67 & 2200 & $10: 04$ & 71 & 2600 & 4753 & $81 \mathrm{~min}$. \\
\hline $8-18$ & $8: 25$ & 63 & 1400 & $8: 38$ & 64 & 3300 & $9: 14$ & 68 & 3600 & $9: 50$ & 71 & 6000 & $220 \delta^{4} 129$ & $72 \mathrm{~min}$. \\
\hline $8-19$ & & & & $7: 43$ & 67 & 640 & $8: 04$ & 67 & 820 & $8: 16$ & 71 & 1400 & $540^{*} \quad 1 ?$ & $33 \mathrm{~min}$. \\
\hline $8-20$ & & & & $7: 00$ & 67 & 120 & $7: 07$ & 68 & 160 & $7: 23$ & 69 & 120 & $14 \hat{0}$ & $23 \mathrm{~min}$. \\
\hline $8-21$ & $7: 15$ & 61 & 1500 & $7: 20$ & 66 & 1300 & $8: 35$ & 68 & 1800 & $8: 50$ & 71 & 2100 & 313 & $90 \mathrm{~min}$. \\
\hline $8-22$ & $7: 45$ & 59 & 360 & $8: 05$ & 63 & 1300 & $9: 12$ & 68 & 1800 & $9: 41$ & 70 & 2600 & $1645^{*} 3629$ & $96 \mathrm{~min}$. \\
\hline $8-23$ & $8: 05$ & 64 & 2000 & $8: 17$ & 69 & 2000 & $8: 38$ & 69 & 2400 & $9: 04$ & 70 & 600 & $43 \quad 24 \%$ & $47 \mathrm{~min}$. \\
\hline $8-24$ & $7: 27$ & 66 & 700 & $7: 49$ & 67 & 540 & $7: 54$ & 68 & 560 & $8: 12$ & 70 & 580 & $1 \% \quad 18 \%$ & $23 \mathrm{~min}$. \\
\hline Mean & $7: 49$ & $61^{\circ}$ & 979 & $8: 07$ & $66^{\circ}$ & 1492 & $8: 32$ & $68^{\circ}$ & 2095 & $9: 00$ & $70^{\circ}$ & 2463 & 188 & $56 \mathrm{~min}$. \\
\hline
\end{tabular}

*Time-A.M. Eastern Central; temperature-Fahrenheit, 6-8 inches above the ground; light-Foot candles, straight up

and in half the flights there were never more than 2 to 4 a minute. (Height of flight was taken as the most consistent flying under what seemed to be the most favourable conditions).

Males flew on all of the 16 flights, although most were gone before the last two. The first 9 flights were exclusively male. No females were seen outside the nest until August 10th and 11th, and they did not have their first flight until August 18 th -22 days after the males began. Most of the females flew on one day, August $22 \mathrm{nd}$, when 362 of them left the nest. Females flew as easily as did males. When one was ready, she simply fluttered her wings rapidly and flew slowly but strongly up into the air. They flew readily from either logs or plants.

The 1961 records for this colony correlated closely with those of 1962 . Each year females took no part in early flights, and most flew on one day. Slightly more flew in 1961 than in
1962 (515 on August 30th and 35 on August 31). Not all of the male flights were seen, but since 1676 males were counted in 6 flights, the number of males flying may also have exceeded the 1962 record. Flights extended later into the month in 1961 because between August 22 and August 29th there was a whole week of rain. Activities of males and females, as well as reactions to temperature and light were identical in the two years.

A comparison with the closely related Formica obscuripes Forel (Talbot, 1959) reveals some differences and some similarities. F. obscuripes flew earlier (in June) and at higher temperatures. Flights could not begin below $69^{\circ} \mathrm{F}$. and they could continue to $81^{\circ} \mathrm{F}$. Both species delayed or stopped flights if temperature decreased or light diminished. In both, the females took no part in the earliest flights and tended to delay flying in the morning until temperatures were 
slightly above those which initiated male flying.

Another Formica at the Reserve, F. ulkei Emery (Talbot, 1959) began flying at temperatures as low as $59^{\circ} \mathrm{F}$. Their flights were also delayed or stopped by decreasing temperature and cloudy sky.

Two other early morning flying ants at the Reserve, Dolichoderus taschenbergi (Mayr), (Kannowski, 1959a) and Dolichoderus mariae Forel, (Talbot, 1956; Kannowski, 1959b), which began flying at $58^{\circ} \mathrm{F}$. seemed more completely controlled by temperature and less by increasing light. They flew on overcast mornings or even in a fog, unless their wings became too wet. However, flights could be ended if the sky became dark and the temperature dropped.

From these studies and other observations, it appears that ants which fly in the early morning are reacting primarily to rising temperature, and that each species has a minimum temperature which triggers flight. Increasing light seems to be very important to some, less so to others. There is variation also in reaction to wind.

\section{Summary}

In southern Michigan the ant Formica obscuriventris Mayr constructs superficial nests under logs and piled-up leaves. Covered runways connect widely spread chambers.
In 1962 one colony released approximately 3000 winged ants in 16 flight days between July 27 and August 24th. An estimated 2587 males flew, and the first nine flights were exclusively male. Females took part in six flights, but most (362 of the 422) flew on one day.

The best flights occurred when bright sun warmed the ground after cold nights. Males could move out of the nest at $57^{\circ} \mathrm{F}$. and could begin flying at $63^{\circ} \mathrm{F}$. They flew best at about $68^{\circ} \mathrm{F}$. and and seemed unable to fly at temperatures above $72^{\circ} \mathrm{F}$. Females began flying at $66^{\circ} \mathrm{F}$. and flew best at $69^{\circ}$ to $70^{\circ} \mathrm{F}$. Any dimming of light delayed or stopped flights even though temperatures might be favourable. Flights were prevented by overcast sky, rain or soaked ground.

\section{R E F E R E N C E S}

Kannowski, P. B. (1959a). The flight activities of Dolichoderus (Hypoclinea) taschenbergi (Hymenoptera: Formicidae). Annals of the Entomological Society of America, 52 (6), 755-760.

Kannowski, P. B. (1959b). The flight activities and colony-founding behavior of bog ants in southeastern Michigan. Insectes Sociaux, 6 (2), 115-162.

Talbot, M. (1956). Flight activities of the ant Dolichoderus (Hypoclinea) mariae Forel. Psyche, 63 (4), 134-139.

Talbot, M. (1959). Flight activities of two species of ants of the genus Formica. The American Midland Naturalist, 61 (1), 124-132.

(Accepted for publication 11th September, 1963; Ms. number: 375). 